Article

\title{
Catalyzed Synthesis and Characterization of a Novel Lignin-Based Curing Agent for the Curing of High-Performance Epoxy Resin
}

\author{
Saeid Nikafshar ${ }^{1}$ (D), Omid Zabihi ${ }^{2, *}$, Yousef Moradi ${ }^{3}$, Mojtaba Ahmadi $^{2}$ (D), Saba Amiri ${ }^{4}$ \\ and Minoo Naebe ${ }^{2}$ \\ 1 Department of Applied Chemistry, Faculty of Chemistry, University of Tabriz, Tabriz 51666, Iran; \\ S_nikafshar@yahoo.com \\ 2 Institute for Frontier Materials, Deakin University, Geelong VIC 3216, Victoria, Australia; \\ mojtaba.ahmadi@ce.iut.ac.ir (M.A.); minoo.naebe@deakin.edu.au (M.N.) \\ 3 Department of Organic Chemistry, Faculty of Chemistry, Isfahan University of Technology, Isfahan \\ 8415683111, Iran; yusefmoradi@yahoo.com \\ 4 Department of Applied Chemistry, Faculty of Chemistry, Urmia University, Urmia 5756151818, Iran; \\ Sabaamiri6767@gmail.com \\ * Correspondence: omid.zabihi@deakin.edu.au; Tel.: +61-469570372
}

Academic Editor: Antonio Pizzi

Received: 19 June 2017; Accepted: 2 July 2017; Published: 4 July 2017

\begin{abstract}
In this study, lignin, an aromatic compound from the forestry industry, was used as a renewable material to synthesize a new aromatic amine curing agent for epoxy resin. Firstly, lignin was separated from black liquor and hydroxyl groups were converted to tosyl groups as leaving groups. Then, primary amination was conducted using an ammonia solution at high pressure and temperature, in the presence of a nano-alumina-based catalyst. The structure of the nanocatalyst was confirmed by FT-IR, ICP, SEM, and XPS analyses. According to the FT-IR spectra, a demethylation reaction, the substitution of hydroxyl groups with tosyl groups, and then an amination reaction were successfully performed on lignin, which was further confirmed by the ${ }^{13} \mathrm{C} N M R$ and CHNS analyses. The active hydrogen equivalent of aminated lignin was determined and three samples with $9.9 \mathrm{wt} \%, 12.9 \mathrm{wt} \%$, and $15.9 \mathrm{wt} \%$ of aminated lignin, as curing agents, were prepared for curing the diglycidyl ether of bisphenol A (DGEBA). The thermal characteristics of the curing process of these epoxy samples were determined by DSC and TGA analyses. Moreover, the mechanical performance of the cured epoxy systems, e.g., the tensile strength and Izod impact strength, were measured, showing that in the presence of $12.9 \mathrm{wt} \%$ aminated lignin, the mechanical properties of the aminated lignin-epoxy system exhibited the best performance, which was competitive, compared to the epoxy systems cured by commercial aromatic curing agents.
\end{abstract}

Keywords: renewable epoxy resin; lignin; curing agent; nanocatalyst

\section{Introduction}

Due to increasing concerns associated with environmental problems such as greenhouse gas emissions, bio-polymers have attracted great attention as a substitution for petroleum-based polymers [1,2]. Natural and renewable resources such as lignin [3], starch [4], poly lactic acid [5], and cellulose [6] are potential candidates for the synthesis of bio-based industrial polymers. Epoxy resins provide a wide range of applications including protective coatings, constructions, components for the electrical and electronic industry, composites, and adhesives due to having a combination of excellent chemical and mechanical properties $[7,8]$. In the presence of curing agents, epoxy resins form 
cross-linked networks in which the reactions of the curing process are irreversible. Several kinds of chemical compounds such as aliphatic and aromatic amines, anhydrides, mercaptans, and phenols can be used to cure epoxy resins [9-11]. Each curing agent has a specific curing profile including the time and temperature, leading to the formation of epoxy networks possessing various physical and mechanical features. For instance, aliphatic amines can cure epoxy resin at room temperature, while the curing of epoxy resins using anhydrides requires higher temperatures [12]. As petroleum-based aliphatic and aromatic amines are generally hazardous materials, they can potentially cause some health and environmental problems $[13,14]$. Therefore, it is necessary to synthesize and develop curing agents from renewable materials to replace petroleum-derived materials with bio-based compounds. Although several bio-based compounds that are able to cure epoxy resins have been found, their numbers are limited, and most importantly, their thermo-mechanical properties are not comparable with petroleum-based curing agents. For instance, furanic amines synthesized from polysaccharides and sugars suffer from low reaction yields [15-17]. Moreover, most bio-based amines, which can be employed as curing agents are amino acids, which are synthesized by either enzymatic or fermentation methods [18]. Lysine [19,20] and tryptophan [21,22] amino acids as curing agents in curing DGEBA have been reported, with studies suggesting that their glass transition temperatures $\left(T_{\mathrm{g}}\right)$ and thermal degradation temperatures are significantly lower than those of petroleum-based curing agents. Furthermore, bio-based anhydrides, as curing agents for epoxy resin, can also be synthesized from various bio-sources such as terpene [23] and rosin [24]. Qin et al. [25] used rosin-based anhydride to cure epoxy resin and the resulting epoxy system had both excellent thermal and mechanical properties. Tannic acid was used as a phenolic curing agent whose results showed that the tensile strength and $T_{\mathrm{g}}$ of the cured epoxy system using this curing agent were lower than those of commercial systems [26]. Aminated grape seed oil was utilized as a polyamine curing agent which formed a cured epoxy network possessing a very low $T_{\mathrm{g}}\left(-38^{\circ} \mathrm{C}\right)$, categorized as an amorphous thermoset polymer [27]. Phenalkamine was extracted from cardanol by the Mannich condensation reaction in the presence of formaldehydes and amines, and it was applied as an amine curing agent to cure epoxy resins $[28,29]$. Although this type of curing agent is set to be deployed as a commercial bio-based curing agent, formaldehyde compounds are hazardous and carcinogenic reactants. Darroman et al. [30] synthesized a new aromatic bio-based amine from cardanol without using formaldehyde, but the thermal and mechanical properties of its cured epoxy network were not satisfactory.

Wang et al. [31] synthesized aminated lignin by the Mannich reaction and it was applied to decolorize anionic azo-dyes. Adding amine groups to lignin increases both lignin's solubility in water and its reactivity with nucleophiles. Moreover, lignin-based amines synthesized via the Mannich reaction were used in waterborne polyurethanes [32]. It was reported that various kinds of aminated lignin improved the mechanical properties and aging resistance of polyurethane systems. In another study, lignin, after being treated with epichlorhydrin and amination by the Mannich reaction, was used to adsorb heavy metals from aqueous solutions [33]. By grafting alkaline lignin with methyl amine and formaldehyde, a Mannich base biosorbent was prepared [34]. In addition, the Mannich reaction was applied to the amination of lignin for different purposes [35-38].

Lignin is the second most plentiful renewable polymer in the earth after cellulose and it can be extracted from wood and annual plants using various extraction methods [39]. Lignin is classified as a phenolic polymer and its chemical structure includes phenylpropane units derived from three aromatic alcohol precursors (monolignols) consisting of $p$-coumaryl, coniferyl, and sinapyl alcohols [40,41]. The chemical structure of lignin is shown in Figure 1. In several studies, epoxy resins have been synthesized by the epoxidation of lignin [42-44]. In addition, it has been used to synthesize phenolic resins, adhesives, polyolefins, and other miscellaneous applications [45]. Pan et al. [46] made a lignin-based epoxy resin from the reaction of epichlorohydrine with lignin and then epoxied lignin was reacted with propane diamine to create a cured epoxy system. The prepared lignin curing agent in the mentioned study possesses a low number of amine groups, requiring a co-curing agent for the full-curing of epoxy resin. Moreover, the lignin-based epoxy resins usually have a low $T_{\mathrm{g}}$ and thermal stability because 
the low number of epoxy rings hinders the formation of a high crosslink density in the cured epoxy system. Therefore, the synthesis of lignin-based curing agents may be preferable to prepare high performance epoxy systems. In this regard, few studies have been done, revealing that the prepared lignin curing agent possesses a low amount of amine groups, requiring a commercial co-curing agent for the full-curing of epoxy resin [47]. In this study, primary amine groups were directly introduced into the lignin structure using a synthesized nanocatalyst of cobalt/copper supported on nanoalumina to enhance the hydrogen amine equivalent of a lignin-based curing agent. Then, this synthesized lignin-based curing agent was used to cure the Diglycidyl Ether of Bisphenol A (DGEBA) epoxy resin, and its thermal and mechanical properties were investigated.

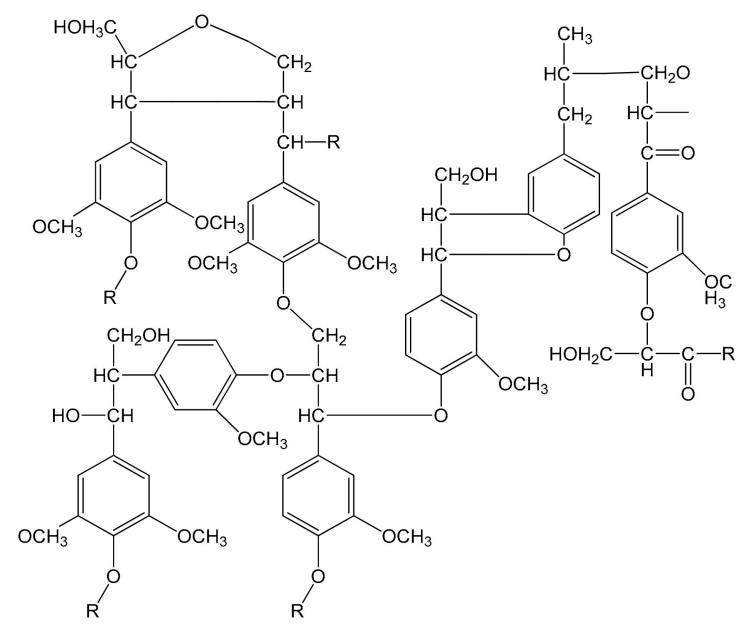

Figure 1. Proposed chemical structure for lignin [48].

\section{Experimental}

\subsection{Materials}

Liquid Diglycidyl Ether of Bisphenol A (Epon 828), with an epoxy equivalent weight of 185-192 g/eq, was purchased from E.V Roberts (Carson, CA, USA). Black liquor containing $43 \mathrm{wt} \%$ waste lignin was supplied from the Kraft pulping of spruce (Choka Company, Anzali, Iran). Sodium sulfite $(98 \%)$, sodium hydroxide $(97 \%)$, hydrochloric acid $(36.5 \%)$, pyridine $(99 \%)$, $p$-toluenesulfonyl chloride (99\%), 1,2 dichloroethane anhydrous (99.8\%), and hydrazine hydrate $(98 \%)$ were purchased from Sigma Aldrich. Cobalt (II) chloride hexahydrate (99\%), cobalt (II) nitrate hexahydrate (99\%), copper (II) nitrate hexahydrate $(99.5 \%)$, and ammonia solution (25\%) were supplied from Merck, Darmstadt, Germany. Nano gamma alumina (99\%, average particle size $20 \mathrm{~nm}$, specific surface area $138 \mathrm{~m}^{2} / \mathrm{g}$ ) was purchased from US Research Nanomaterials Inc.

\subsection{Methods}

\subsubsection{Synthesis of Nanocatalyst for Amination Reaction}

Firstly, $25 \mathrm{~g}$ nanoalumina, $2.5 \mathrm{~g} \mathrm{Co}\left(\mathrm{NO}_{3}\right)_{2} \cdot 6 \mathrm{H}_{2} \mathrm{O}$, and $2.5 \mathrm{~g} \mathrm{Cu}\left(\mathrm{NO}_{3}\right)_{2} \cdot 6 \mathrm{H}_{2} \mathrm{O}$ were mixed with $100 \mathrm{~mL}$ distilled water and the mixture was then poured into a $1 \mathrm{~L}$ reactor (batch reactor, Payafanavar), followed by stirring at $200 \mathrm{rpm}$ for $4 \mathrm{~h}$ at $140{ }^{\circ} \mathrm{C}$. After $2 \mathrm{~h}, 40 \mathrm{~g}$ hydrazine hydrate, as a reducing agent, was added to the mixture. Afterwards, the total mixture was filtrated and the obtained sediments were placed in an oven at $100{ }^{\circ} \mathrm{C}$ for $1 \mathrm{~h}$, and then calcined in a furnace at $400{ }^{\circ} \mathrm{C}$ for $3 \mathrm{~h}$.

\subsubsection{Separation Lignin from Black Liquor}

In order to separate the lignin from black liquor by ultrafiltration, it was necessary to decrease its viscosity by diluting it with an aqueous solution of acetic acid of $50 \%$ (volume ratio: $1: 3$ ). To remove 
the impurities, $100 \mathrm{~mL}$ diluted black liquor was poured in a dead-end filtration cell under nitrogen pressure to drive the liquor through the lab-made membrane. The membrane was made from $18 \%$ polyethersulphone containing $1 \%$ polyvinylpyrrolidone. The remaining lignin was collected and put in the oven at $40{ }^{\circ} \mathrm{C}$ for $24 \mathrm{~h}$ to obtain a completely dried lignin powder.

\subsubsection{Synthesis of Lignin-Based Curing Agent}

The synthesis of the lignin-based curing agent consists of three steps, as follows. In the first step, for the demethylation of lignin, $115.1 \mathrm{~g}$ lignin, $115.1 \mathrm{~g}$ distillated water, and $11.5 \mathrm{~g} \mathrm{Na}_{2} \mathrm{SO}_{3}$ were mixed in a $300 \mathrm{~mL}$ flask, and $11.5 \mathrm{~g} \mathrm{NaOH}$ was then added to increase the solubility of lignin. $\mathrm{Na}_{2} \mathrm{SO}_{3}$ acts as a demethylation reagent of lignin. The mixture was stirred at $1000 \mathrm{rpm}$ at $90{ }^{\circ} \mathrm{C}$ for $1 \mathrm{~h}$. Then, the mixture was cooled down to room temperature and the $\mathrm{pH}$ was adjusted to 2 by a $\mathrm{HCl}$ solution of $1 \%(v / v)$. The demethylated lignin was precipitated and separated from the solution by a centrifugation process. Afterwards, it was washed three times with distilled water to reach neutral $\mathrm{pH}$. The demethylated lignin particles were placed in the vacuum oven at $50{ }^{\circ} \mathrm{C}$ for $12 \mathrm{~h}$ prior to use.

In the second step, since hydroxyl groups are not good leaving groups and are not reactive in substitution reactions, they have to be replaced by strong leaving groups such as OTs. For this purpose, $30 \mathrm{~g}$ demethylated lignin was dissolved in $50 \mathrm{~mL}$ pyridine, and $100 \mathrm{~g}$ 4-toluenesulfonyl chloride was then added to this solution. Afterwards, $13.5 \mathrm{~g} \mathrm{CoCl}_{2} \cdot 6 \mathrm{H}_{2} \mathrm{O}, 100 \mathrm{~mL} \mathrm{1,2} \mathrm{dichloroethane} \mathrm{anhydrous,}$ and $50 \mathrm{~mL}$ distilled water were further added to the total solution and the resulting solution was refluxed at $60^{\circ} \mathrm{C}$ for $1 \mathrm{~h}$. Then, the organic phase was extracted and washed two times with a saturated solution of $\mathrm{NaHCO}_{3}$, and it was dried in a vacuum oven at $40{ }^{\circ} \mathrm{C}$ for $2 \mathrm{~h}$. In the abovementioned reactions, hydroxyl groups were converted to leaving groups of OTs.

In the final step, $3.30 \mathrm{~g}$ functionalized lignin with OTs obtained from step 2, was dissolved in $50 \mathrm{~mL}$ pyridine and $200 \mathrm{~mL}$ ammonia solution of $25 \%$, and then $15 \mathrm{~g}$ synthesized nanoalumina-based catalyst was added to this solution, before being poured into a high pressure batch reactor. The pressure and temperature were adjusted to $22 \mathrm{bar}$ and $180^{\circ} \mathrm{C}$, respectively, for $2 \mathrm{~h}$ under mechanical stirring (IKA RW 20) at $200 \mathrm{rpm}$. Afterwards, the resulting mixture was cooled down and $50 \mathrm{~mL}$ $\mathrm{NaOH}$ solution $(50 \mathrm{wt} \%$ ) was slowly added to neutralize the total mixture. To separate the aminated lignin from other side products, a fractionating column was used at $105^{\circ} \mathrm{C}$. In Figure 2, all steps of the synthesis of a lignin-based curing agent are schematically presented.
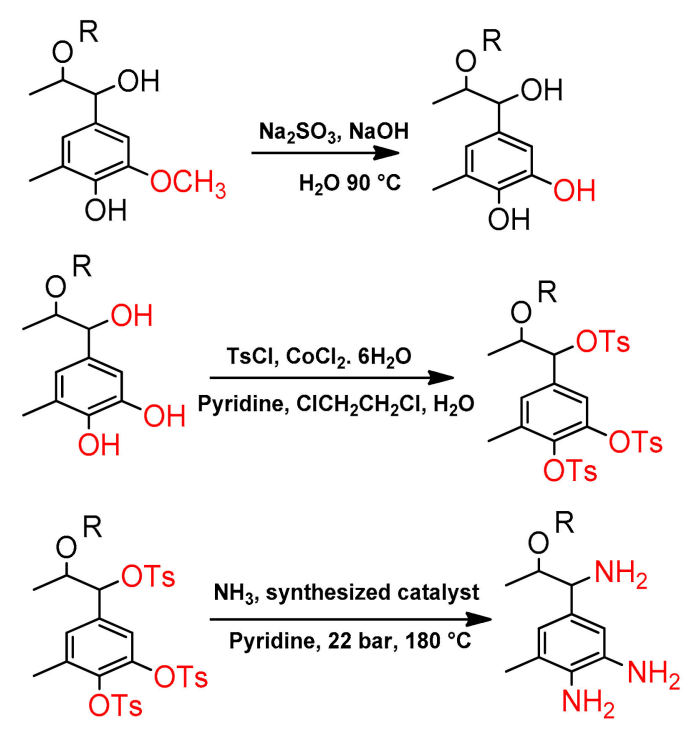

Figure 2. All steps in the synthesis of a lignin-based curing agent. 


\subsubsection{Epoxy Systems Preparation}

Firstly, to utilize the synthesized lignin-based curing agent for the full curing of epoxy resin, its active hydrogen equivalent (AHE) should be calculated. In this regard, the lignin-based curing agent was dissolved in dioxane containing $10 \%$ distillated water, and the solution was titrated by a $\mathrm{HCl}$ solution of $1 \mathrm{~N}$. Using the following equation, $\mathrm{AHE}$ can be determined:

$$
\frac{W \times 1000}{A \times N}=\mathrm{AHE}
$$

where $A$ is $\mathrm{mL}$ of consumed $\mathrm{HCl}, \mathrm{N}$ is the normality of the $\mathrm{HCl}$ solution, and $W$ is the weight of the sample used in titration. The AHE obtained was $24.3 \mathrm{~g} / \mathrm{eq}$. Each active hydrogen can react with one epoxy group and the stoichiometric ratio of the synthesized lignin-based curing agent for the reaction with epoxy resin is calculated according to the following equation:

\section{AHE \\ $\overline{\mathrm{EEW}}$}

where AHE is the active hydrogen equivalent of the curing agent and EEW is the average epoxy equivalent weight of epoxy resin. Therefore, the obtained stoichiometric ratio of the lignin-based curing agent and epoxy resin is 0.129 .

To prepare the cured epoxy samples, $100 \mathrm{~g}$ epoxy resin was mixed with $12.9 \mathrm{~g}$ lignin-based curing agent, dissolved in a small amount of tetrahydrofuran. It is worth mentioning that since lignin is a large molecule, it is possible that some amine groups cannot react with epoxy rings mainly due to the steric hindrance. Therefore, cured epoxy samples with lower and higher stoichiometric ratio values were also prepared as follows: sample A $9.9 \mathrm{wt} \%$; sample B $12.9 \mathrm{wt} \%$; sample C $15.9 \mathrm{wt} \%$. As the melting point of the lignin-based curing agent was too high $\left(>250^{\circ} \mathrm{C}\right)$, it was firstly dissolved in a suitable solvent to react well with the epoxy resin. Various amounts of lignin-based curing agent were dissolved in a small amount of tetrahydrofuran, and then the solution was added into a proper amount of epoxy resin. The mixture was vigorously stirred using a mechanical mixer (IKA RW 20) at $500 \mathrm{rpm}$ for $5 \mathrm{~min}$ and degassed under vacuum to remove the solvent for $10 \mathrm{~h}$ at $50^{\circ} \mathrm{C}$. The curing reaction was conducted at $125^{\circ} \mathrm{C}$ for $2 \mathrm{~h}$, followed by a post curing for $1 \mathrm{~h}$ at $150^{\circ} \mathrm{C}$.

\subsection{Characterizations}

The FT-IR analysis was carried out using an FT-IR spectrometer, Tensor 27, (Bruker, Billerica, MA, USA) Bruker with a 40 scan average at a resolution of $4 \mathrm{~cm}^{-1}$. The ${ }^{13} \mathrm{C}$ NMR spectrum of aminated lignin was obtained at ambient temperature using a Bruker Spectrospin Avanc $400 \mathrm{MHZ}$ NMR. (Bruker Spectrospin, Billerica, MA, USA) Chemical shifts were determined relative to tetramethyl silane (TMS), which was applied as the control. The ${ }^{13} \mathrm{C}$ NMR spectrum was acquired with a relaxation delay time of $1 \mathrm{~s}$ and a spectral width of $100,000 \mathrm{~Hz}$. The crystalline structure of yjr synthesized nanocatalyst was studied using X-ray diffraction (XRD) with Siemens D5000 (Siemens, Munich, Germany) equipment. To measure and quantify the loaded elements on the gamma nanoalumina as support for the nanocatalyst, inductivity coupled plasma (ICP), using Integra XL equipment, was conducted. Lignin, before and after the amination reaction, was analyzed to determine its elemental composition in the CHNS mode via CHNS Elemental Analyzer Vario EL III machining using helium as a carrier gas, and the amount of oxygen was determined by the difference. The DSC analysis was performed using Linseis, PT10 (Linseis, Robbinsville, NJ) equipment from USA, to investigate the thermal curing characteristics. The DSC machine was firstly calibrated using standard zinc and indium. For each experiment, a $5 \mathrm{mg}$ sample was sealed with an aluminum pan and then tested in the DSC machine using a non-isothermal DSC mode with a heating rate of $10{ }^{\circ} \mathrm{C} / \mathrm{min}$ under a nitrogen flow of $40 \mathrm{~mL} / \mathrm{min}$ at a temperature range of -30 to $200^{\circ} \mathrm{C}$. A DSC re-scan was performed on the cured epoxy systems at a heating rate of $10^{\circ} \mathrm{C} /$ min to determine the glass transition temperature $\left(T_{\mathrm{g}}\right)$. Thermogravimetric analysis (TGA) was 
performed using TG/DTA 6300 (SII Nanotechnology, Northridge, CA, USA) under nitrogen flow over a temperature range of $0-700{ }^{\circ} \mathrm{C}$ at a heating rate of $10^{\circ} \mathrm{C} / \mathrm{min}$. A tensile strength test was conducted in accordance with ASTM D638 Type I by using a Shimadzu 20KN-testing (Shimadzu, Kyoto, Japan) machine. Specimen dimensions of samples were selected to be $165 \times 19 \times 3.2 \mathrm{~mm}^{3}$, and the crosshead speed was adjusted to $2 \mathrm{~mm} / \mathrm{min}$. At least five specimens were made and tested. The Izod impact strength test was conducted according to an ASTM D256 by a Zwick/Roll 6103 impact tester at room temperature using specimens with dimensions of $63.5 \times 12.7 \times 7.2 \mathrm{~mm}^{3}$. For each sample, five replicates were tested. Fracture surfaces of the cured epoxy systems after the Izod impact strength test and the surface of the synthesized nanocatalyst were observed by employing SEM analyses using a Tescan, MIRA3 FEG-SEM, (Tescan, Kohoutovice) Czech Republic, at an accelerating voltage of $5.00 \mathrm{KV}$.

\section{Results and Discussion}

\subsection{Nanocatalyst Characterization}

Due to the high surface area, high pore volume, pore-size distribution, acid/base characteristics, local microstructure, and being able to phase combination, $\gamma$-nanoalumina is widely used as a catalyst, as well as support for other catalysts, in various industries [49,50]. In the present study, to synthesize the nano size of cobalt and copper metal nanoparticles and apply them as catalysts in the amination reaction, cobalt nitrate hexahydrate and copper nitrate hexahydrate salts were reduced using hydrazine in the porous spaces of $\gamma$-nanoalumina. In other words, the synthesized cobalt and copper nanoparticles were trapped in the porous spaces, catalyzing the amination reaction without the dispersion of the reaction in the environment of [51]. It is proposed that the reduction reactions of cobalt nitrate hexahydrate and copper nitrate hexahydrate salts are according to the following reactions:

$$
\begin{aligned}
& \mathrm{Co}\left(\mathrm{NO}_{3}\right)_{2} \cdot 6 \mathrm{H}_{2} \mathrm{O}+3 \mathrm{~N}_{2} \mathrm{H}_{4} \stackrel{140^{\circ} \mathrm{C}}{\rightarrow} \mathrm{Co}+4 \mathrm{~N}_{2}+12 \mathrm{H}_{2} \mathrm{O} \\
& \mathrm{Cu}\left(\mathrm{NO}_{3}\right)_{2} \cdot 6 \mathrm{H}_{2} \mathrm{O}+3 \mathrm{~N}_{2} \mathrm{H}_{4} \stackrel{1400^{\circ} \mathrm{C}}{\rightarrow} \mathrm{Cu}+4 \mathrm{~N}_{2}+12 \mathrm{H}_{2} \mathrm{O}
\end{aligned}
$$

In order to confirm the chemical structure of the synthesized nanocatalyst, FT-IR spectroscopy was carried out, and its result is shown in Figure 3a. The absorption peaks at $573 \mathrm{~cm}^{-1}$ and $800 \mathrm{~cm}^{-1}$ are assigned to the stretching mode of $\mathrm{AlO}_{6}$, and the absorption peaks at $1074 \mathrm{~cm}^{-1}$ and $1161 \mathrm{~cm}^{-1}$ are related to the symmetric bending and asymmetric stretching of $\mathrm{Al}-\mathrm{O}-\mathrm{Al}$, respectively $[52,53]$. Two absorption peaks at $1522 \mathrm{~cm}^{-1}$ and $3553 \mathrm{~cm}^{-1}$ can also be assigned to the bending and stretching $\mathrm{OH}$ groups, respectively [54]. Vibration peaks around $1000-1200 \mathrm{~cm}^{-1}$ are attributed to $\mathrm{Cu}-\mathrm{O}-\mathrm{Al}$ and $\mathrm{Co}-\mathrm{O}-\mathrm{Al}$, which were overlapped with the asymmetric stretching of $\mathrm{Al}-\mathrm{O}-\mathrm{Al}$. The XRD pattern of the synthesized nanocatalyst is illustrated in Figure $3 \mathrm{~b}$, demonstrating XRD peaks at $2 \theta$ of $38.5^{\circ}$, $44.5^{\circ}$, and $65.0^{\circ}$, which are related to gamma alumina nanoparticles [55]. This shows that during the loading of cobalt and copper nanoparticles, the structure of gamma nanoalumina has not been changed. Moreover, the peaks which appeared in the range of $50-52^{\circ}$ are assigned to the cobalt and copper nanoparticles [56]. Furthermore, cobalt oxide and copper oxide should only be seen in the XRD pattern if the concentration of these metal oxides is more than $5 \mathrm{wt} \%$ with respect to the nanoalumina. Since in the XRD pattern, the peak of these metal oxides cannot be seen, it can be concluded that most of the cobalt and copper ions were completely reduced. However, as mentioned earlier, only $30 \%$ of reduced cobalt and copper ions are supported on the nanoalumina surface. Figure $3 \mathrm{c}$ shows an SEM image of the synthesized nanocatalyst, illustrating that cobalt and copper nanoparticles are loaded on the nanoalumina surface. The size of the loaded cobalt and copper are calculated to be $\sim 29-44 \mathrm{~nm}$. Inductivity coupled plasma (ICP) analysis provides information regarding the loaded metals on the support. The results of ICP analysis are presented in Figure 3d. As can be seen, the amount of loaded cobalt and copper on the nanoalumina is $\sim 0.7 \mathrm{gr}$ and they are almost equal, which is due to the fact that their reactivity is the same. In addition, only $\sim 30 \%$ of the used metal ions were loaded on the nanoalumina. 

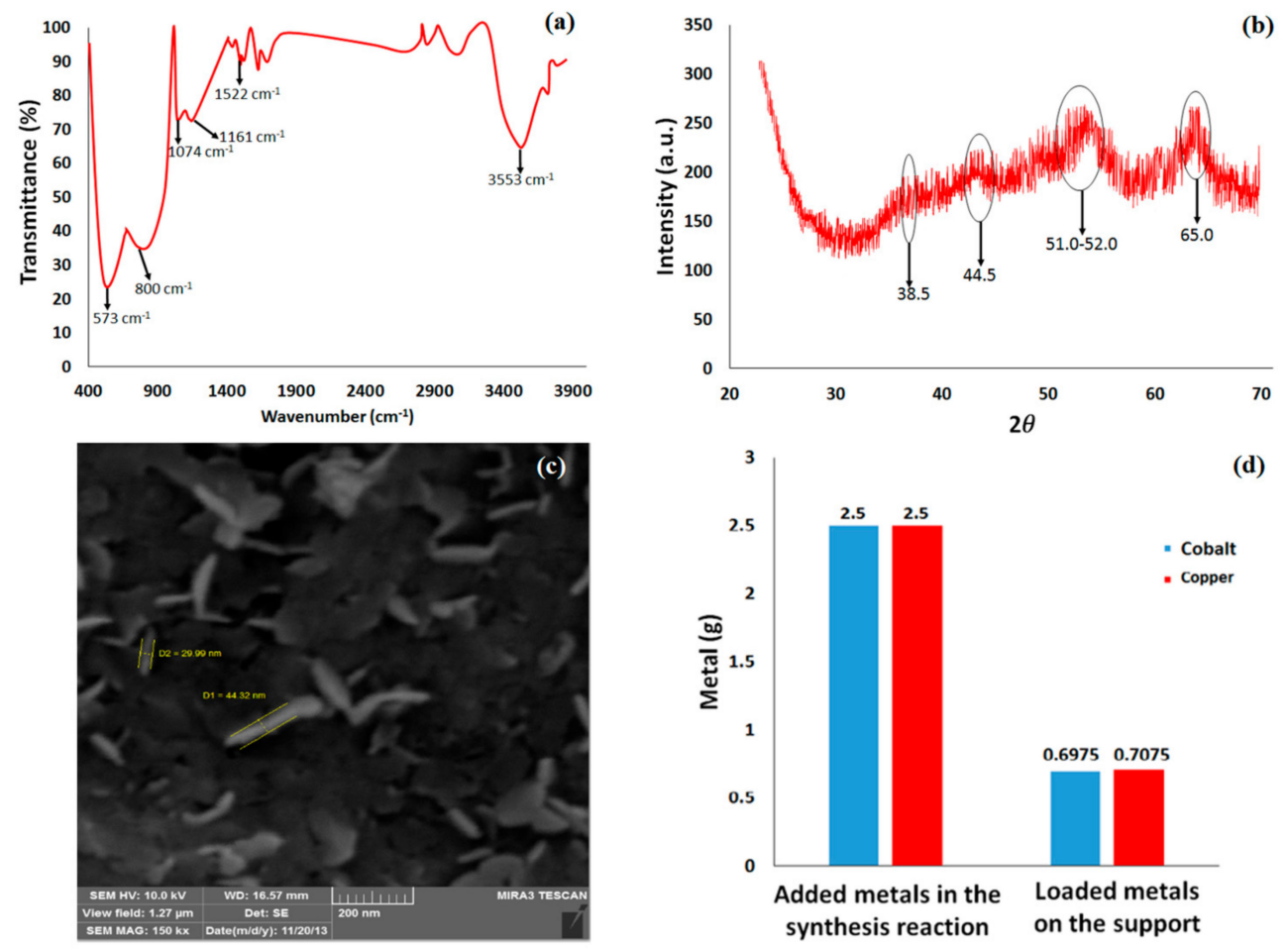

Figure 3. FT-IR spectrum (a); XRD pattern (b); SEM image (c); and ICP analysis (d) of the synthesized nanocatalyst.

\subsection{Lignin-Based Curing Agent Characterization}

Generally, the amination reactions, catalyzed by cobalt/copper-supported on the nanoalumina, include the coordination of the nucleophile to the metal center, activation of the $\mathrm{C}-\mathrm{X}$ bond (X means leaving group), and $\mathrm{C}-\mathrm{N}$ bond formation. It is proposed that the used metal nanoparticles act as a catalyst according to the oxidative addition/reductive elimination pathway [57], and its reactions are shown in Figure 4. Herein, the coordination of OT groups with metal nanoparticles provides a better nucleophilic property on their neighbor carbon, which can induce a more nucleophilic attack of ammonium groups. Consequently, ammonium groups can be more easily substituted with OTs, forming a primary amine, whilst cobalt and copper return to the initial transition state and $p$-toluenesulfonic acid is formed. This is in agreement with the literature, which has shown that the reaction of aryl tosylates with ammonia generates amine groups [58-60].<smiles>[R]OC(C)C(N)c1cc(C)c([O-])c([18OH])c1</smiles>

Figure 4. Proposed mechanisms of cobalt/copper catalyzed amination reactions.

FTIR spectroscopy was performed to study the chemical structure of lignin before modification, after demethylation, and after amination. Figure 5a presents the FTIR spectrum of the separated lignin from black liquor, before modification. A broad absorption peak around $3400 \mathrm{~cm}^{-1}$ corresponds to the 
stretch vibration of $\mathrm{O}-\mathrm{H}$ groups. Absorption peaks at $2926 \mathrm{~cm}^{-1}$ and $1458 \mathrm{~cm}^{-1}$ are assigned to the $\mathrm{C}-\mathrm{H}$ vibrations of $-\mathrm{CH}_{2}$ and $-\mathrm{CH}_{3}$ groups, respectively. While, $\mathrm{C}-\mathrm{H}$ vibration of the $-\mathrm{CH}_{3} \mathrm{O}$ groups shows an absorption bond at $2831 \mathrm{~cm}^{-1}$. Moreover, the absorption bonds at $1610 \mathrm{~cm}^{-1}$ and $1517 \mathrm{~cm}^{-1}$ represent the presence of aromatic $C=C$ vibrations. Absorption peaks that appeared at $1274 \mathrm{~cm}^{-1}$ and $1033 \mathrm{~cm}^{-1}$ are characteristic peaks of $\mathrm{C}-\mathrm{O}$ vibrations [61,62]. After the demethylation of lignin, the FTIR spectrum (Figure $5 \mathrm{~b}$ ) shows that the intensity of absorption peaks of -OH and $\mathrm{C}-\mathrm{O}$ vibrations appearing at $3400 \mathrm{~cm}^{-1}, 1030 \mathrm{~cm}^{-1}$, and $1210 \mathrm{~cm}^{-1}$ is significantly increased. Moreover, since the number of methyl groups decreased as a result of demethylation reactions, the absorption intensity of the $\mathrm{C}-\mathrm{H}$ vibration peak at $2926 \mathrm{~cm}^{-1}$ reduced. According to this FTIR spectrum, it can be proved that most of the methyl groups are converted to the hydroxyl groups. Figure $5 \mathrm{c}$ illustrates the FTIR spectrum of lignin after the amination reaction, presenting two absorption peaks at $3300 \mathrm{~cm}^{-1}$ and $3500 \mathrm{~cm}^{-1}$ that corresponded to the $\mathrm{N}-\mathrm{H}$ stretching vibration. Moreover, vibration bonds at $1540 \mathrm{~cm}^{-1}$ and $1350 \mathrm{~cm}^{-1}$ are related to the $\mathrm{N}-\mathrm{H}$ bending vibration and $\mathrm{C}-\mathrm{N}$ vibration, respectively. An absorption peak around $800 \mathrm{~cm}^{-1}$ is also assigned to the out of plan $\mathrm{N}-\mathrm{H}$ vibration [63]. Additionally, there is a medium small peak with a low intensity around $3500 \mathrm{~cm}^{-1}$ associated with some remaining hydroxyl groups, which are negligible compared to the introduced amine groups.
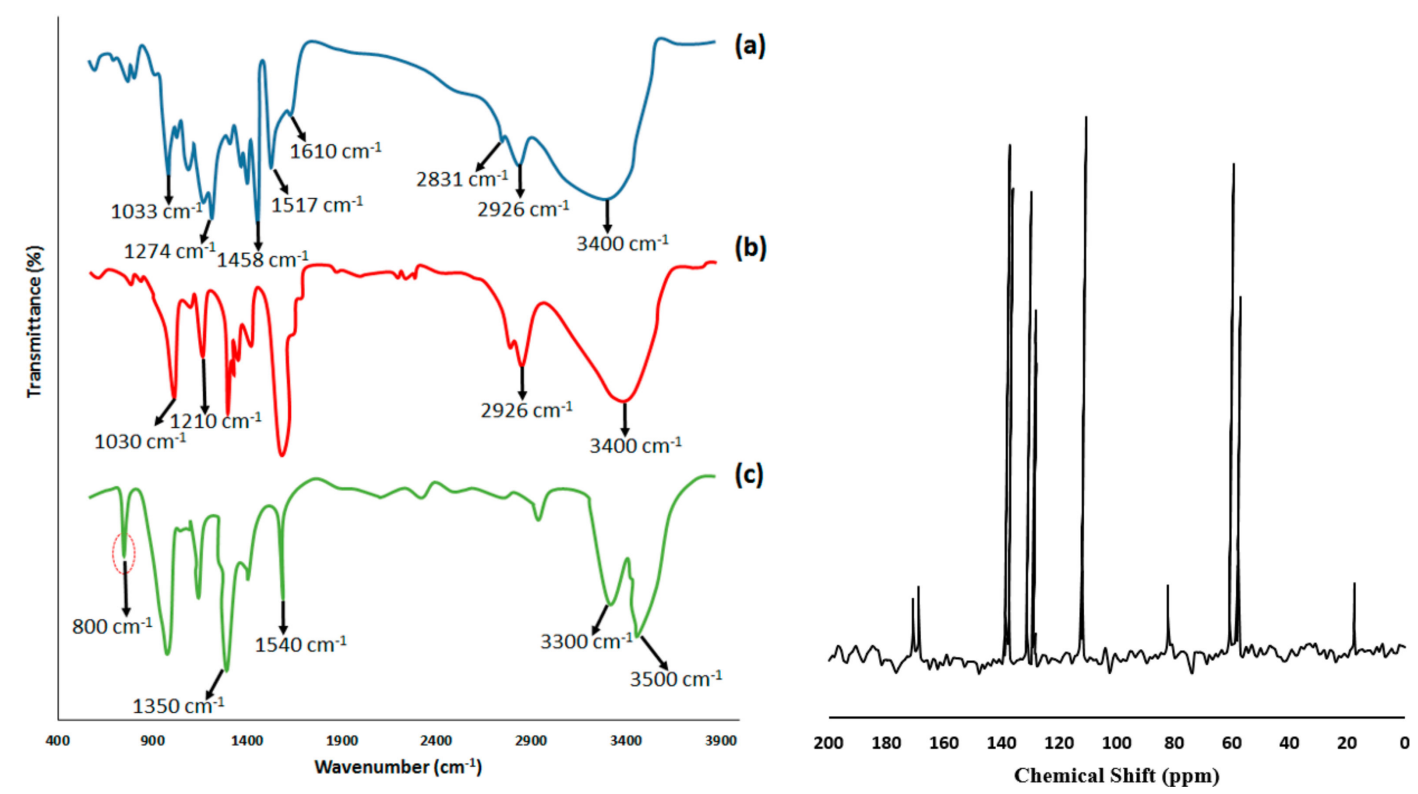

Figure 5. FTIR spectra (left) of separated lignin (a); demethylated lignin (b); and aminated lignin (c); ${ }^{13} \mathrm{C}$ NMR spectrum (right) of aminated lignin.

The ${ }^{13} \mathrm{C}$ NMR of the spectrum of aminated lignin is presented in Figure 5. The peaks around $130 \mathrm{ppm}$ are attributed to the substituted ortho and para carbon sites on the aromatic ring. The peaks at 16.5 and $17.8 \mathrm{ppm}$ are related to methyl groups. The $\mathrm{CH}$ group which is connected to the aromatic ring and amine group has a peak at $59.5 \mathrm{ppm}$. The peak at $82.2 \mathrm{ppm}$ is assigned to $\mathrm{CH}$, which is connected to oxygen. It can be supposed that the peaks at 136.8 and $137.3 \mathrm{ppm}$ are assigned to aromatic carbons which are connected to amine groups. The results of CHNS analysis are also presented in Table 1. The carbon and oxygen contents of pure separated lignin decreased after the amination reaction, while the hydrogen and nitrogen content increased. These changes can be attributed to amination reactions in which hydroxyl and methoxyle groups were converted to primary amine groups. The sulfur content after amination was reduced slightly due to the fact that pure separated lignin was subjected to the purification as a result of dissolving in various solvents. 
Table 1. CHNS analyses of lignin before and after amination.

\begin{tabular}{cccccc}
\hline Type of Lignin & Carbon (\%) & Hydrogen (\%) & Oxygen (\%) & Nitrogen (\%) & Sulfur (\%) \\
\hline Separated lignin & 57.16 & 4.61 & 34.17 & 1.68 & 1.56 \\
Aminated lignin & 55.87 & 7.58 & 29.82 & 4.63 & 1.39 \\
\hline
\end{tabular}

\subsection{Thermal Properties of Epoxy Systems}

DSC provides useful information about the curing conditions of epoxy systems and many studies have been performed on the epoxy resin to obtain kinetic data using DSC analyses [64-66]. The DSC thermograms of three samples are shown in Figure 6 and their results are presented in Table 2. In sample A ( $9.9 \mathrm{wt} \%$ aminated lignin), the onset temperature $\left(T_{\mathrm{i}}\right)$ and peak temperature $\left(T_{\mathrm{p}}\right)$ are 114.1 and $124.8^{\circ} \mathrm{C}$, respectively, whereas the $T_{\mathrm{i}}$ and $T_{\mathrm{p}}$ values of sample $\mathrm{B}(12.9 \mathrm{wt} \%$ aminated lignin) are 102.6 and $129.4^{\circ} \mathrm{C}$, respectively. A comparison on the total heat of the curing reaction $(\Delta H)$ of samples $\mathrm{A}$ and $\mathrm{B}$ confirms that $\Delta H$ of sample $\mathrm{A}$ is much lower than that of sample $\mathrm{B}$. It is worth mentioning that the opening of epoxy rings by amine groups is an exothermic reaction; therefore, when more epoxy groups are opened in the structure, a higher heat will be released. It means that in sample A, all epoxy groups did not undergo ring-opening reactions, which may be due to the fact that the amount of curing agent in sample A was not sufficient to react with all epoxy groups. The $\Delta H$ of sample B was about two times higher than that of sample A. Moreover, in sample $C$, the amount of curing agent increased and consequently the $T_{\mathrm{i}}$ dropped to $93.9^{\circ} \mathrm{C}$, indicating that the curing reaction of epoxy resin was initiated much sooner than those of samples $\mathrm{A}$ and $\mathrm{B}$ as a result of more amine groups available to react with epoxy rings at low temperatures. Furthermore, the $T_{p}$ of sample $C$ is $121.2^{\circ} \mathrm{C}$, which is lower than that of the peak temperatures of samples $\mathrm{A}$ and $\mathrm{B}$, showing that the curing reaction in sample $\mathrm{C}$ is completed sooner compared to the other samples. The $\Delta H$ of sample $\mathrm{C}$ is $684.36 \mathrm{~J} / \mathrm{g}$, which is higher than that of samples B and A. This means that in sample C, more epoxy groups reacted with amine groups. According to these results, it can be concluded that the amount of curing agent in sample $\mathrm{A}$ is not sufficient and the curing reaction of epoxy resin in sample A remains incomplete. On the other hand, no significant differences between samples $B$ and $C$ were observed in terms of their curing characteristics.
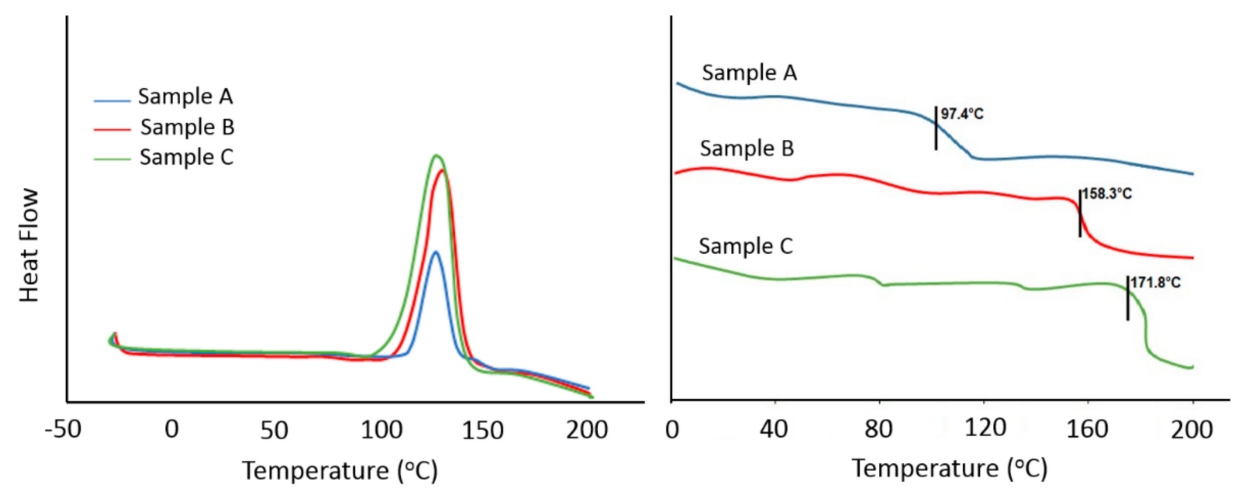

Figure 6. DSC thermograms of various un-cured samples (left), and re-scan DSC thermograms of cured samples (right) at heating rate of $10^{\circ} \mathrm{C} / \mathrm{min}$.

Table 2. Thermal characteristics of the curing process of the various samples obtained from DSC analyses at a heating rate of $10^{\circ} \mathrm{C} / \mathrm{min}$.

\begin{tabular}{cccccc}
\hline Sample Code & Curing Agent $(\mathbf{P h r})$ & $\boldsymbol{T}_{\mathbf{i}}\left({ }^{\circ} \mathbf{C}\right)$ & $\boldsymbol{T}_{\mathbf{p}}\left({ }^{\circ} \mathbf{C}\right)$ & $\boldsymbol{\Delta} \boldsymbol{H}(\mathbf{J} / \mathbf{g})$ & $\boldsymbol{T}_{\mathbf{g}}\left({ }^{\circ} \mathbf{C}\right)$ \\
\hline A & 9.9 & 114.1 & 124.8 & 317.21 & 97.4 \\
B & 12.9 & 102.6 & 129.4 & 628.79 & 158.3 \\
C & 15.9 & 93.9 & 121.2 & 684.36 & 171.8 \\
\hline
\end{tabular}


The $T_{\mathrm{g}}$ is directly related to the polymer chain mobility and performance of the curing process, and consequently, the formed epoxy network [67]. As can be seen from Figure 6 (right) and Table 2, the $T_{\mathrm{g}}$ of sample A (9.9 wt \% curing agent) is $97.4^{\circ} \mathrm{C}$, which is much lower than the $T_{\mathrm{g}}$ of sample $\mathrm{B}$ (12.9 $\mathrm{wt} \%$ curing agent). This tangible difference can be associated to that the fact that the crosslink density in sample A is lower than that of sample B, which may be indicate that sample A is not completely cured. In sample $\mathrm{C}$ ( $15.9 \mathrm{wt} \%$ curing agent), $T_{\mathrm{g}}$ is $171.8{ }^{\circ} \mathrm{C}$, which is $8.5 \%$ higher than sample $B$, while the amount of curing agent used in sample $C$ is $23.2 \%$ which is more than the amount of curing agent in sample B. As discussed earlier, lignin is a macromolecule containing a high number of aromatic rings. Therefore, when the amount of aminated lignin used as a curing agent increases, the number of both aromatic rings and amine groups increases, and we would thus expect that the crosslink density of the epoxy structure enhances, and consequently, $T_{\mathrm{g}}$ is improved. It is worth mentioning that a higher $T_{\mathrm{g}}$ means a more rigid epoxy network $[68,69]$.

The thermal stability of the three samples has also been examined using TGA analysis, and the results are illustrated in Figure 7 and Table 3. As can be seen, there are two degradation stages for all samples, which can be assigned to the degradation of the aliphatic parts (first stage) and aromatic parts (second stage) of the epoxy matrix [70]. Sample A has the lowest onset degradation temperature ( $\left.T_{\text {onset }}\right)$ among the samples, which is due to the low crosslink density and low number of aromatic structures. The $T_{\text {onset }}$ samples B and C are about 243 and $239^{\circ} \mathrm{C}$, respectively. In sample $\mathrm{C}$, it is supposed that the amount of aminated lignin is excess; therefore, all of them are not entered into the curing reaction. This remaining lignin-based curing agent led to a decrease in the thermal stability of the system.

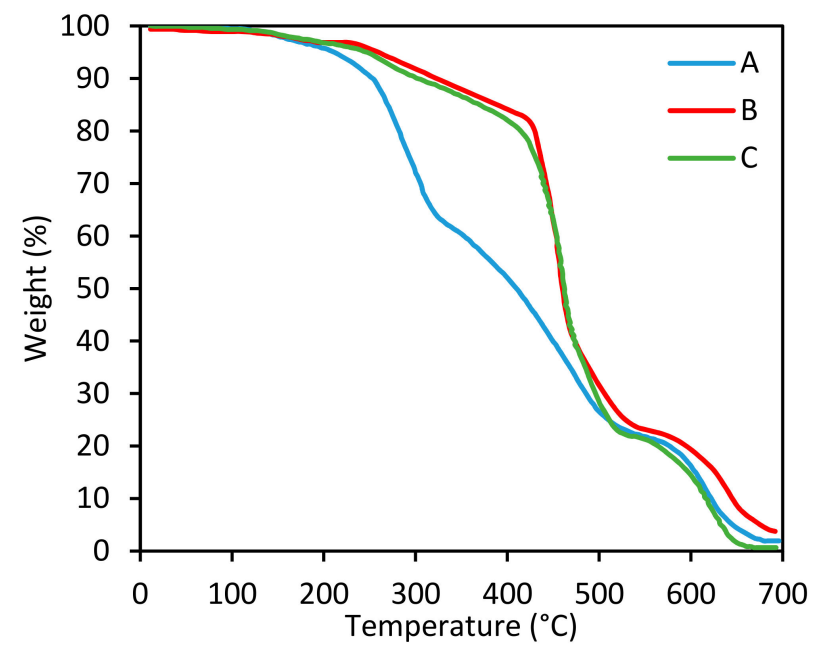

Figure 7. TGA curves of the various samples at a heating rate of $10^{\circ} \mathrm{C} / \mathrm{min}$.

According to Table 3, the degradation temperature at $5 \%$ weight loss $\left(T_{5 \%}\right)$ of sample $\mathrm{A}$ is lower than those of samples B and C. Moreover, sample $C$ has a lower $T_{5 \%}$, compared with sample $B$. As is expected, the temperature at the maximum rate of degradation $\left(T_{\max }\right)$ of sample $\mathrm{A}$ is also lower than the $T_{\max }$ of samples $B$ and $C$, while samples $B$ and $C$ have similar $T_{\max }$ values.

Table 3. Thermal stability characteristics of the samples obtained from TGA analysis.

\begin{tabular}{ccccc}
\hline Sample Code & Curing Agent (Phr) & $\boldsymbol{T}_{\text {onset }}\left({ }^{\circ} \mathbf{C}\right)$ & $\boldsymbol{T}_{\mathbf{5} \%}\left({ }^{\circ} \mathbf{C}\right)$ & $\boldsymbol{T}_{\max }\left({ }^{\circ} \mathbf{C}\right)$ \\
\hline A & 9.9 & 172.7 & 257.7 & 286.6 \\
B & 12.9 & 243.2 & 309.8 & 456.2 \\
C & 15.9 & 239.4 & 297.1 & 457.9 \\
\hline
\end{tabular}




\subsection{Mechanical Performance of Epoxy Systems}

According to Table 4, tensile modulus and elongation at the break of sample A are higher than those of other samples. This can be attributed to the more flexible structure in sample A. As it was mentioned, the epoxy matrix in sample A was not fully cured and there are some remaining epoxy groups due to an insufficient amount of curing agent. This leads to a higher elongation at the break for sample A, while the tensile strength of sample A is the lowest among all the samples. On the other hand, sample B has the highest tensile strength, while its elongation at the break is lower than that of sample A. This is due to its higher crosslink density which results in the fact that its chemical bonds cannot be easily elongated under mechanical load compared to sample A. In sample C, both the tensile strength and elongation at the break are lower than those of sample B. It is supposed that due to the higher $T_{\mathrm{g}}$, the crosslink density in sample $\mathrm{C}$ is higher than that of sample $\mathrm{A}$ and consequently, it becomes more brittle $[65,71]$. In addition, it can be argued that the amount of remaining aminated lignin as curing agent in sample $\mathrm{C}$ can act as a filler, resulting in an improvement of the tensile strength. Gupta el al. [72] cured DGEBA epoxy resin using $14.5 \mathrm{wt} \%$ aromatic amine of metaphenylene diamine and obtained a tensile strength of $\sim 82 \mathrm{MPa}$. While in the present study, the tensile strength of sample B was $86.1 \mathrm{MPa}$, which is $5 \%$ higher than that of the value reported by Gupta et al. It means that this synthesized lignin-based curing agent can compete with commercially available curing agents in terms of its mechanical properties.

Table 4 also presents the impact of the Izod strength of various samples. In sample A, the Izod impact strength is $27.11 \mathrm{~kJ} / \mathrm{m}^{2}$, while it reaches $35.73 \mathrm{~kJ} / \mathrm{m}^{2}$ and $34.29 \mathrm{~kJ} / \mathrm{m}^{2}$ for samples $\mathrm{B}$ and $\mathrm{C}$, respectively. As discussed earlier, this difference can be attributed to the fact that not all of the epoxy groups were cured in sample A; therefore, it can absorb a lower energy compared to the other samples. Here, it can be assumed that sample $C$ is brittle due to the high amount of curing agent; however, an excess amount of curing agent (unreacted aminated lignin) can play a role as a filler and consequently compensates for the brittleness of the epoxy structure to some extent. For this reason, samples C and B have approximately the same Izod impact strength. Fang-Fu et al. [73] cured epoxy resin with 4,4'-diaminodiphenylmethan as the curing agent and reported an Izod impact strength of $6.7 \mathrm{~kJ} / \mathrm{m}^{2}$, whereas the Izod impact strength of sample A in this study is $433 \%$ higher than that of value reported by Fang-Fu et al.

Table 4. Tensile strength, tensile modulus, and elongation at the break of various samples.

\begin{tabular}{|c|c|c|c|c|c|}
\hline $\begin{array}{l}\text { Sample } \\
\text { Code }\end{array}$ & $\begin{array}{c}\text { Curing } \\
\text { Agent (Phr) }\end{array}$ & $\begin{array}{c}\text { Tensile Strength } \\
\text { (MPa) }\end{array}$ & $\begin{array}{c}\text { Tensile Modulus } \\
\text { (MPa) }\end{array}$ & $\begin{array}{c}\text { Elongation at } \\
\text { Break }(\%)\end{array}$ & $\begin{array}{c}\text { Izod Impact } \\
\text { Strengths }\left(\mathrm{kJ} / \mathrm{m}^{2}\right)\end{array}$ \\
\hline $\mathrm{A}$ & 9.9 & $43.47 \pm 2.6$ & $4104.71 \pm 38.5$ & $4.46 \pm 0.37$ & 27.11 \\
\hline B & 12.9 & $86.91 \pm 4.3$ & $3029.64 \pm 54.6$ & $3.23 \pm 0.62$ & 35.73 \\
\hline $\mathrm{C}$ & 15.9 & $79.12 \pm 4.7$ & $3467.28 \pm 45.8$ & $2.17 \pm 0.22$ & 34.29 \\
\hline
\end{tabular}

\subsection{Morphological Observations}

Figure 8 presents the fracture surfaces of various cured samples at two different magnifications (750 $\mu \mathrm{m}$ and $300 \mu \mathrm{m}$ ). As can be seen, the surface of sample A is mostly smooth and only a few fracture surfaces are observed. On the other hand, in sample B, cracks propagate in the labyrinth matrix, causing more fractured plates, and the surface is completely jagged and rough. In sample $\mathrm{C}$, the surface is rough and fractured plates are also present; however, their numbers are lower than that of sample B. It is hypothesized that extra amounts of curing agent were trapped among cured epoxy chains, acting as a filler. Therefore, the surface is rough even though sample $\mathrm{C}$ is brittle. 

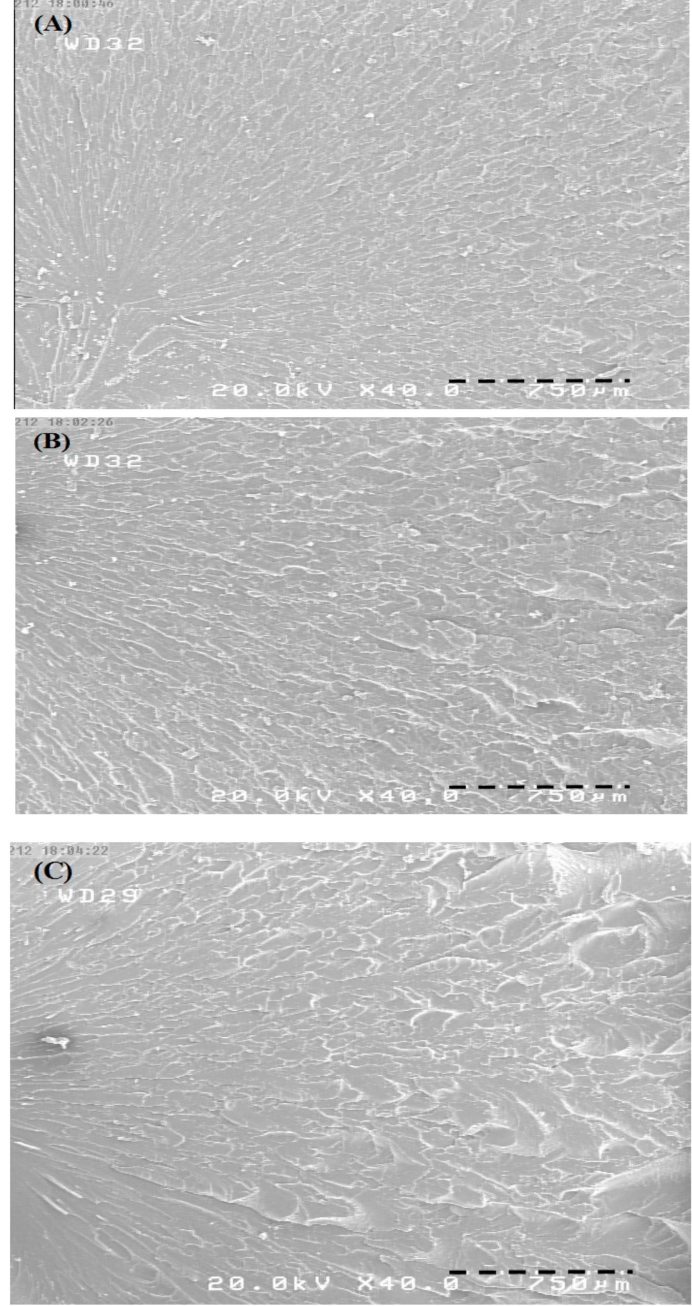
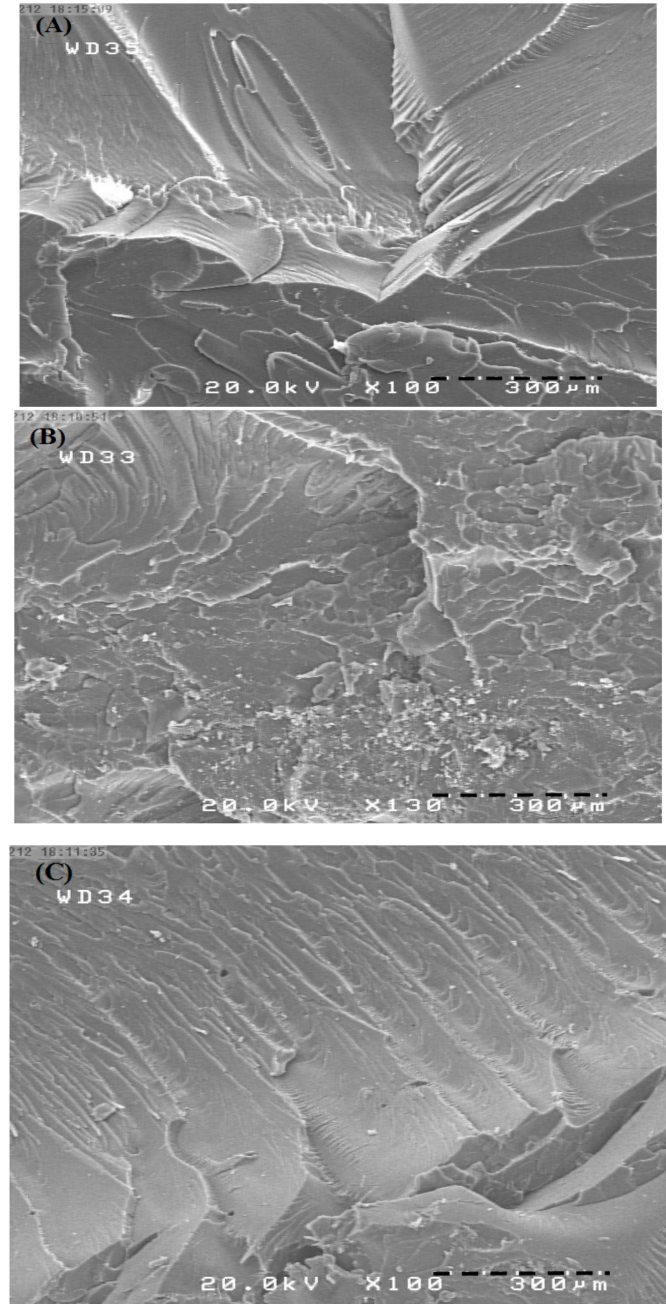

Figure 8. SEM images of the fracture surfaces of the various samples at different magnifications ((A) $9.9 \mathrm{wt} \%$ curing agent; (B) $12.9 \mathrm{wt} \%$ curing agent; and (C) $15.9 \mathrm{wt} \%$ curing agent).

\section{Conclusions}

In summary, the lignin was modified to be used as a bio-based curing agent for epoxy resin. Towards to this end, lignin functional groups were firstly converted to hydroxyl groups through a demethylation process, before being converted to a tosyle-lignin intermediate. Then, an amination reaction was conducted on tosyle-lignin to introduce primary amine groups into the lignin structure, which was catalyzed by a cobalt/copper supported nanoalumina. Using FTIR and ${ }^{13} \mathrm{C}$ NMR analyses, the chemical structure of the lignin-based curing agent was successfully confirmed. Moreover, FT-IR spectroscopy was used to identify the chemical structure of the synthesized nanocatalyst. The ICP analysis illustrated that $27.9 \mathrm{wt} \%$ and $28.3 \mathrm{wt} \%$ of cobalt and copper were loaded on nanoalumina, respectively. The active hydrogen equivalent (AHE) of aminated lignin was then determined by titration to find the stoichiometric ratio of aminated lignin and epoxy resin. The aminated lignin was then used as a bio-based curing agent in the curing of a high performance DGEBA epoxy resin system. The results showed that there is no a direct relationship between the calculated stoichiometric ratio with thermal and mechanical properties. It is argued that since the synthesized lignin-based curing agent is a macromolecule with steric hindrance when involved in the curing process, a higher amount of lignin-based curing agent can change the thermal and mechanical properties. However, according to the obtained results, high $T_{\mathrm{g}}$ and $T_{\text {onset }}$ values, as well as a high tensile strength and Izod impact strength, can be confirmed by the application of this synthesized lignin-based curing 
agent in the preparation of a high performance cured epoxy system, which can compete fairly with the commercially available aromatic curing agents.

Acknowledgments: The authors would like to gratefully thank the University of Tabriz for the financial support for this research project.

Author Contributions: The study was conceived and designed by Saeid Nikafshar and Yousef Moradi. Experiments were conducted by Saeid Nikafshar, Yousef Moradi, and Saba Amiri. Data and results were analyzed by Saeid Nikafshar, Omid Zabihi, Yousef Moradi, and Mojtaba Ahmadi with the support of Minoo Naebe. The first draft was written by Saeid Nikafshar. Minoo Naebe reviewed and revised the manuscript to produce its final form.

Conflicts of Interest: The authors declare no conflict of interest.

\section{References}

1. Ma, S.; Liu, X.; Jiang, Y.; Tang, Z.; Zhang, C.; Zhu, J. Bio-based epoxy resin from itaconic acid and its thermosets cured with anhydride and comonomers. Green Chem. 2013, 15, 245-254. [CrossRef]

2. Nikafshar, S.; Zabihi, O.; Hamidi, S.; Moradi, Y.; Barzegar, S.; Ahmadi, M.; Naebe, M. A renewable bio-based epoxy resin with improved mechanical performance that can compete with dgeba. RSC Adv. 2017, 7, 8694-8701. [CrossRef]

3. Oroumei, A.; Fox, B.; Naebe, M. Thermal and rheological characteristics of biobased carbon fiber precursor derived from low molecular weight organosolv lignin. ACS Sustain. Chem. Eng. 2015, 3, 758-769. [CrossRef]

4. Zhao, R.; Torley, P.; Halley, P.J. Emerging biodegradable materials: Starch- and protein-based bio-nanocomposites. J. Mater. Sci. 2008, 43, 3058-3071. [CrossRef]

5. Avella, M.; Buzarovska, A.; Errico, M.E.; Gentile, G.; Grozdanov, A. Eco-challenges of bio-based polymer composites. Materials 2009, 2, 911-925. [CrossRef]

6. Kalia, S.; Dufresne, A.; Cherian, B.M.; Kaith, B.; Avérous, L.; Njuguna, J.; Nassiopoulos, E. Cellulose-based bio-and nanocomposites: A review. Int. J. Polym. Sci. 2011, 2011, 837875. [CrossRef]

7. Xiong, X.; Ren, R.; Liu, S.; Lu, S.; Chen, P. The curing kinetics and thermal properties of epoxy resins cured by aromatic diamine with hetero-cyclic side chain structure. Thermochim. Acta 2014, 595, 22-27. [CrossRef]

8. Ren, R.; Xiong, X.; Ma, X.; Liu, S.; Wang, J.; Chen, P.; Zeng, Y. Isothermal curing kinetics and mechanism of dgeba epoxy resin with phthalide-containing aromatic diamine. Thermochim. Acta 2016, 623, 15-21. [CrossRef]

9. Zabihi, O.; Khayyam, H.; Fox, B.L.; Naebe, M. Enhanced thermal stability and lifetime of epoxy nanocomposites using covalently functionalized clay: Experimental and modelling. New J. Chem. 2015, 39, 2269-2278. [CrossRef]

10. Zabihi, O. Preparation and characterization of toughened composites of epoxy/poly(3,4-ethylenedioxythiophene) nanotube: Thermal, mechanical and electrical properties. Compos. B Eng. 2013, 45, 1480-1485. [CrossRef]

11. Mirmohseni-Namin, A.; Nikafshar, S.; Mirmohseni, F. Increasing toughness and tensile strength of an epoxy-diamine system using an inorganic ultra-accelerator. RSC Adv. 2015, 5, 53025-53035. [CrossRef]

12. Petrie, E. Epoxy Adhesive Formulations; McGraw-Hill Education: New York, NY, USA, 2005.

13. Tsantzalis, S.; Karapappas, P.; Vavouliotis, A.; Tsotra, P.; Paipetis, A.; Kostopoulos, V.; Friedrich, K. Enhancement of the mechanical performance of an epoxy resin and fiber reinforced epoxy resin composites by the introduction of cnf and pzt particles at the microscale. Compos. A Appl. Sci. Manuf. 2007, 38, 1076-1081. [CrossRef]

14. Plastics Europe Epoxy Resins Committee. Epoxy Resins and Curing Agents: Toxicology, Health, Safety and Environmental Aspects; Plastics Europe Epoxy Resins Committee: Brussels, Belgium, 2006.

15. Le, N.-T.; Byun, A.; Han, Y.; Lee, K.-I.; Kim, H. Preparation of 2, 5-bis (aminomethyl) furan by direct reductive amination of 2, 5-diformylfuran over nickel-raney catalysts. Green Sustain. Chem. 2015, 5, 115. [CrossRef]

16. Hu, F.; Yadav, S.K.; La Scala, J.J.; Sadler, J.M.; Palmese, G.R. Preparation and characterization of fully furan-based renewable thermosetting epoxy-amine systems. Macromol. Chem. Phys. 2015, 216, 1441-1446. [CrossRef]

17. Fache, M.; Montérémal, C.; Boutevin, B.; Caillol, S. Amine hardeners and epoxy cross-linker from aromatic renewable resources. Eur. Polym. J. 2015, 73, 344-362. [CrossRef] 
18. Ding, C.; Matharu, A.S. Recent developments on biobased curing agents: A review of their preparation and use. ACS Sustain. Chem. Eng. 2014, 2, 2217-2236. [CrossRef]

19. Triantafyllidis, K.S.; LeBaron, P.C.; Park, I.; Pinnavaia, T.J. Epoxy-clay fabric film composites with unprecedented oxygen-barrier properties. Chem. Mater. 2006, 18, 4393-4398. [CrossRef]

20. Metkar, P.S.; Scialdone, M.A.; Moloy, K.G. Lysinol: A renewably resourced alternative to petrochemical polyamines and aminoalcohols. Green Chem. 2014, 16, 4575-4586. [CrossRef]

21. Li, Y.; Xiao, F.; Wong, C. Novel, environmentally friendly crosslinking system of an epoxy using an amino acid: Tryptophan-cured diglycidyl ether of bisphenol a epoxy. J. Polym. Sci. A Polym. Chem. 2007, 45, 181-190. [CrossRef]

22. Motahari, A.; Rostami, A.A.; Omrani, A.; Ehsani, M. On the thermal degradation of a novel epoxy-based nanocomposite cured with tryptophan as an environment-friendly curing agent. J. Macromol. Sci. B 2015, 54, 517-532. [CrossRef]

23. Takahashi, T.; Hirayama, K.I.; Teramoto, N.; Shibata, M. Biocomposites composed of epoxidized soybean oil cured with terpene-based acid anhydride and cellulose fibers. J. Appl. Polym. Sci. 2008, 108, 1596-1602. [CrossRef]

24. Wang, H.; Liu, X.; Liu, B.; Zhang, J.; Xian, M. Synthesis of rosin-based flexible anhydride-type curing agents and properties of the cured epoxy. Polym. Int. 2009, 58, 1435-1441. [CrossRef]

25. Qin, J.; Liu, H.; Zhang, P.; Wolcott, M.; Zhang, J. Use of eugenol and rosin as feedstocks for biobased epoxy resins and study of curing and performance properties. Polym. Int. 2014, 63, 760-765. [CrossRef]

26. Shibata, M.; Teramoto, N.; Makino, K. Preparation and properties of biocomposites composed of epoxidized soybean oil, tannic acid, and microfibrillated cellulose. J. Appl. Polym. Sci. 2011, 120, 273-278. [CrossRef]

27. Stemmelen, M.; Lapinte, V.; Habas, J.-P.; Robin, J.-J. Plant oil-based epoxy resins from fatty diamines and epoxidized vegetable oil. Eur. Polym. J. 2015, 68, 536-545. [CrossRef]

28. Huang, K.; Zhang, Y.; Li, M.; Lian, J.; Yang, X.; Xia, J. Preparation of a light color cardanol-based curing agent and epoxy resin composite: Cure-induced phase separation and its effect on properties. Prog. Org. Coat. 2012, 74, 240-247. [CrossRef]

29. Pathak, S.K.; Rao, B. Structural effect of phenalkamines on adhesive viscoelastic and thermal properties of epoxy networks. J. Appl. Polym. Sci. 2006, 102, 4741-4748. [CrossRef]

30. Darroman, E.; Bonnot, L.; Auvergne, R.; Boutevin, B.; Caillol, S. New cardanol-based aromatic amines for the synthesis of biobased epoxy networks. Eur. J. Lipid Sci. Technol. 2014, 117, 178-189. [CrossRef]

31. Wang, X.; Zhang, Y.; Hao, C.; Dai, X.; Zhou, Z.; Si, N. Ultrasonic-assisted synthesis of aminated lignin by a mannich reaction and its decolorizing properties for anionic azo-dyes. RSC Adv. 2014, 4, 28156-28164. [CrossRef]

32. Liu, J.; Liu, H.-F.; Deng, L.; Liao, B.; Guo, Q.-X. Improving aging resistance and mechanical properties of waterborne polyurethanes modified by lignin amines. J. Appl. Polym. Sci. 2013, 130, 1736-1742. [CrossRef]

33. Liu, X.; Zhu, H.; Qin, C.; Zhou, J.; Zhao, J.R.; Wang, S. Adsorption of heavy metal ion from aqueous single metal solution by aminated epoxy-lignin. BioResources 2013, 8, 2257-2269. [CrossRef]

34. Ge, Y.; Song, Q.; Li, Z. A mannich base biosorbent derived from alkaline lignin for lead removal from aqueous solution. J. Ind. Eng. Chem. 2015, 23, 228-234. [CrossRef]

35. Dilling, P.; Falkehag, S. Process for Producing Cationic Lignin Amines. U.S. Patent 3,718,639, 27 Feberury 1973.

36. Naae, D.G.; Whittington, L.E.; Ledoux, W.A.; DeBons, F.E. Surfactants from Lignin. U.S. Patent 4,739,040, 19 April 1988.

37. Schilling, P. Sulfomethylated Lignin Amines. U.S. Patent 4,859,362, 8 October 1988.

38. Wang, M.; Sjöholm, E.; Li, J. Fast and reliable quantification of lignin reactivity via reaction with dimethylamine and formaldehyde (mannich reaction). Holzforschung 2017, 71, 27-34. [CrossRef]

39. Laurichesse, S.; Avérous, L. Chemical modification of lignins: Towards biobased polymers. Prog. Polym. Sci. 2014, 39, 1266-1290. [CrossRef]

40. Dorrestijn, E.; Laarhoven, L.J.; Arends, I.W.; Mulder, P. The occurrence and reactivity of phenoxyl linkages in lignin and low rank coal. J. Anal. Appl. Pyrolysis 2000, 54, 153-192. [CrossRef]

41. Ralph, J.; Lundquist, K.; Brunow, G.; Lu, F.; Kim, H.; Schatz, P.F.; Marita, J.M.; Hatfield, R.D.; Ralph, S.A.; Christensen, J.H.; et al. Lignins: Natural polymers from oxidative coupling of 4-hydroxyphenyl- propanoids. Phytochem. Rev. 2004, 3, 29-60. [CrossRef] 
42. Ferdosian, F.; Yuan, Z.; Anderson, M.; Xu, C.C. Synthesis of lignin-based epoxy resins: Optimization of reaction parameters using response surface methodology. RSC Adv. 2014, 4, 31745-31753. [CrossRef]

43. Sasaki, C.; Wanaka, M.; Takagi, H.; Tamura, S.; Asada, C.; Nakamura, Y. Evaluation of epoxy resins synthesized from steam-exploded bamboo lignin. Ind. Crops Prod. 2013, 43, 757-761. [CrossRef]

44. Jafari, H.; Afshar, S.; Zabihi, O.; Naebe, M. Enhanced photocatalytic activities of tio2-sio2 nanohybrids immobilized on cement-based materials for dye degradation. Res. Chem. Intermed. 2016, 42, 2963-2978. [CrossRef]

45. Stewart, D. Lignin as a base material for materials applications: Chemistry, application and economics. Ind. Crops Prod. 2008, 27, 202-207. [CrossRef]

46. Pan, H.; Sun, G.; Zhao, T. Synthesis and characterization of aminated lignin. Int. J. Biol. Macromol. 2013, 59, 221-226. [CrossRef] [PubMed]

47. Pan, H.; Sun, G.; Zhao, T.; Wang, G. Thermal properties of epoxy resins crosslinked by an aminated lignin. Polym. Eng. Sci. 2015, 55, 924-932. [CrossRef]

48. Adler, E. Lignin chemistry-Past, present and future. Wood Sci. Technol. 1977, 11, 169-218. [CrossRef]

49. Ward, J.; Leach, B. Applied Industrial Catalysis; Leach, B.E., Ed.; Elsevier: Amsterdam, The Netherlands, 1984; Volume 3, pp. 271-392.

50. Wefers, K. Alumina Chemicals: Science and Technology Handbook; The American Ceramic Society: Westerville, $\mathrm{OH}, \mathrm{USA}, 1990$.

51. Trueba, M.; Trasatti, S.P. Г-alumina as a support for catalysts: A review of fundamental aspects. Eur. J. Inorg. Chem. 2005, 2005, 3393-3403. [CrossRef]

52. Lee, J.S.; Kim, H.S.; Park, N.-K.; Lee, T.J.; Kang, M. Low temperature synthesis of $\alpha$-alumina from aluminum hydroxide hydrothermally synthesized using [al(c2o4)x(oh)y] complexes. Chem. Eng. J. 2013, 230, 351-360. [CrossRef]

53. Parida, K.M.; Pradhan, A.C.; Das, J.; Sahu, N. Synthesis and characterization of nano-sized porous gamma-alumina by control precipitation method. Mater. Chem. Phys. 2009, 113, 244-248. [CrossRef]

54. El-Naggar, A.Y. Characterization of modified and polymer coated alumina surfaces by infrared spectroscopy. J. Spectrosc. 2013, 2013, 706960. [CrossRef]

55. Rozita, Y.; Brydson, R.; Scott, A. An investigation of commercial gamma- $\mathrm{Al}_{2} \mathrm{O}_{3}$ nanoparticles. J. Phys. 2010, 241, 012096.

56. Salavati-Niasari, M.; Davar, F.; Mazaheri, M.; Shaterian, M. Preparation of cobalt nanoparticles from [bis(salicylidene)cobalt(ii)]-oleylamine complex by thermal decomposition. J. Magn. Magn. Mater. 2008, 320, 575-578. [CrossRef]

57. Sperotto, E.; van Klink, G.P.; van Koten, G.; de Vries, J.G. The mechanism of the modified ullmann reaction. Dalton Trans. 2010, 39, 10338-10351. [CrossRef] [PubMed]

58. Aubin, Y.; Fischmeister, C.; Thomas, C.M.; Renaud, J.-L. Direct amination of aryl halides with ammonia. Chem. Soc. Rev. 2010, 39, 4130-4145. [CrossRef] [PubMed]

59. Klinkenberg, J.L.; Hartwig, J.F. Catalytic organometallic reactions of ammonia. Angew. Chem. Int. Ed. 2011, 50, 86-95. [CrossRef] [PubMed]

60. Vo, G.D.; Hartwig, J.F. Palladium-catalyzed coupling of ammonia with aryl chlorides, bromides, iodides and sulfonates: A general method for the preparation of primary arylamines. J. Am. Chem. Soc. 2009, 131, 11049. [CrossRef] [PubMed]

61. Pandey, K. A study of chemical structure of soft and hardwood and wood polymers by ftir spectroscopy. J. Appl. Polym. Sci. 1999, 71, 1969-1975. [CrossRef]

62. Tejado, A.; Pena, C.; Labidi, J.; Echeverria, J.; Mondragon, I. Physico-chemical characterization of lignins from different sources for use in phenol-formaldehyde resin synthesis. Bioresour. Technol. 2007, 98, 1655-1663. [CrossRef] [PubMed]

63. Pavia, D.L.; Lampman, G.M.; Kriz, G.S.; Vyvyan, J.A. Introduction to Spectroscopy; Cengage Learning: Boston, MA, USA, 2008.

64. Zabihi, O. Modeling of phenomenological mechanisms during thermal formation and degradation of an epoxy-based nanocomposite. Thermochim. Acta 2012, 543, 239-245. [CrossRef]

65. Zabihi, O.; Khodabandeh, A.; Ghasemlou, S. Investigation of mechanical properties and cure behavior of dgeba/nano-fe2o3 with polyamine dendrimer. Polym. Degrad. Stab. 2012, 97, 1730-1736. [CrossRef] 
66. Zabihi, O.; Aghaie, M.; Zare, K. Study on a novel thermoset nanocomposite form dgeba-cycloaliphatic diamine and metal nanoparticles. J. Therm. Anal. Calorim. 2013, 111, 703-710. [CrossRef]

67. Tant, M.R.; Hill, A.J. Structure and Properties of Glassy Polymers; American Chemical Society; Distributed by Oxford University Press: Washington, DC, USA, 1998.

68. Fox, T.G., Jr.; Flory, P.J. Second-order transition temperatures and related properties of polystyrene. I. Influence of molecular weight. J. Appl. Phys. 1950, 21, 581-591. [CrossRef]

69. Podgorski, L. Analysis of the wood coating ageing and prediction of the durability through calorimetric investigations. Proc. Wood Coat. Syst. Wood-Cost E18 2004, 12, 88-92.

70. Chung, H.; Washburn, N.R. Improved lignin polyurethane properties with lewis acid treatment. ACS Appl. Mater. Interfaces 2012, 4, 2840-2846. [CrossRef] [PubMed]

71. Manson, J.A.; Sperling, L.H.; Kim, S.L. Influence of Crosslinking on the Mechanical Properties of High $t(g)$ Polymers; DTIC: Bethlehem, PA, USA, 1977.

72. Gupta, V.; Drzal, L.; Lee, C.C.; Rich, M. The temperature-dependence of some mechanical properties of a cured epoxy resin system. Polym. Eng. Sci. 1985, 25, 812-823. [CrossRef]

73. Fu, J.F.; Shi, L.Y.; Zhong, Q.D.; Chen, Y.; Chen, L.Y. Thermally conductive and electrically insulative nanocomposites based on hyperbranched epoxy and nano- $\mathrm{Al}_{2} \mathrm{O}_{3}$ particles modified epoxy resin. Polym. Adv. Technol. 2011, 22, 1032-1041. [CrossRef]

(C) 2017 by the authors. Licensee MDPI, Basel, Switzerland. This article is an open access article distributed under the terms and conditions of the Creative Commons Attribution (CC BY) license (http:/ / creativecommons.org/licenses/by/4.0/). 